\title{
Determinants Of Job Satisfaction And Retention Of Mexican-American Accounting Professionals
}

Glen D. Moyes, (E-mail: glenmoyes@utpa.edu), University of Texas, Pan-American Angelica C. Cortes, University of Texas, Pan-American Ping Lin, California State University, Long Beach

\begin{abstract}
This study examines differences in work-related values (e.g., compensation, coworkers, and supervisors) between the Mexican-American and the Non-Hispanic White Accounting Professional. Using a survey research design, questionnaires are sent to accounting alumnae of two universities: (1) a primarily Mexican-American public university and (2) a primarily Non-Hispanic White private college. Tests indicate that while Mexican-American respondents are less satisfied with compensation, benefits, and supervisors, they have greater overall job satisfaction than the NonHispanic White respondent. This result is also statistically significant when the two groups are compared by gender and age. One explanation is that the Mexican-American culture includes values such as loyalty to one's employer and job longevity that are not as appreciated by Non-Hispanic Whites.
\end{abstract}

\section{INTRODUCTION}

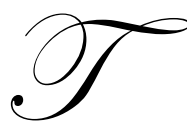

his study investigates the factors that may influence the level of job satisfaction and retention of Hispanic American accounting professionals. Considering the high projected growth of Hispanic Americans, they are still grossly underrepresented in many fields, specifically in both the accounting education and accounting profession. According to the American Institute of Certified Public Accountants (AICPA, 1998), only eight percent of all the 1996 new bachelor of accounting graduates was Hispanics and at the master level, only five percent of the graduates was Hispanics. These graduation percentages illustrate a serious underrepresentation problem when contrasted to 10.8 percent of the 1996 total U.S. population being Hispanic (US Census Bureau, 1998). In terms of the profession, AICPA (1998) recorded in 1996 that Hispanic represented only four percent of the total 24,800 accounting majors hired by CPA firms. During the same year, Hispanics represented a mere one percent of all CPAs employed by CPA firms (AICPA, 1998).

In addition to the Hispanic under-representation in the accounting profession, the supply of accounting graduates is decreasing each subsequent year, which complicates the overall problem even further. According to the American Institute of Certified Public Accountants (2003), the number of new accounting graduates declined from 61,220 in 1994-95 down to 44,695 in 2001-02. With the supply of accounting graduates decreasing, it becomes more critical for the employers to focus more attention on the issues of job satisfaction and retention. Mynatt et al, (1997) indicated that two problems exist in relation to Hispanic American accountants: (1) recruiting them into the accounting profession, and (2) retaining them into the profession. This study attempts to address both problems by identifying the factors that we think may influence the level of job satisfaction that is considered important to Hispanic American accounting professionals which directly influences the retention rate. In particular, we studied the issues confronting Mexican Americans, which represent 67 percent of the Hispanic American group 


\section{LITERATURE REVIEW}

According to studies by Lankau and Scandura (1996), McNeely (1989), Bartell (1981), and Chusmir and Koberg (1990), Hispanic minority employees experience higher overall job satisfaction compared to the Anglo majority. Likewise, Hawkes et al. (1984), found that Hispanic employees experienced greater satisfaction, when they have been accepted and respected by their co-workers, whereas Anglo-Saxon employees tend to experience more satisfaction from jobs with higher compensation. These cultural differences on what are important for each group are indicative of the complexity of the factors that influences job satisfaction and retention for various ethnic groups, including the Anglo majority and the Hispanic minority.

This research attempts to investigate and understand the major factors that affect job satisfaction, which may assist employers to attract and retain more Hispanic Americans in the profession, in particular Mexican Americans. To conduct this study, we surveyed 1000 Mexican American accounting professionals from which 143 submitted complete and usable questionnaires. These respondents were accounting graduates from a regional Texas state university, located near to the Mexican border. The analysis shows six major factors that may influence the level of job satisfaction perceived by these Hispanic American accounting graduates. These factors are: (1) employee acceptance by their supervisors and peers, (2) supervision issues, (3) compensation dollar amount, (4) job enjoyment, (5) employee treatment regardless of race and gender issues, and (6) corporate environment.

\section{Education And Career Expectations}

Most Mexican American students at this university are first generation attending college. On the average, the parents' level of education of the students surveyed in this study is less than the eighth grade (De los Santos et al., 2002). An article published by the Dallas Morning News (July 10, 2003), confirmed that according to the Department of Education, one-third of Hispanics dropped out of high school. Consequently, when the children go to college, they have a larger need for role models and mentors (De los Santos et al., 2002).

Green (1992) found that first generation college students are attracted to majors that have a very clear link to careers, e.g. accounting majors to the accounting career. For female students, Douvan (1976) found that when the mother works outside the home, their daughters tend to select majors that will result in prestigious careers compared to those whose mothers are full-time homemakers. However, Leppel (2001) found that first generation Hispanic students tend to select business majors when (1) socioeconomic status, (2) parent's education, and (3) father's occupation are relatively low. As these variables change for the second generation, the probability of majoring in business might decrease.

\section{Work Environment And Career Growth}

In relation to the work environment, Wheeler (2004) found that employees are extremely productive, when (1) they feel accepted by their supervisors and (2) the organizational environment is open to racial diversity, which in turn leads to innovation and creativity. In this situation, supervisors are supportive, listen and value their employees' opinions, which are consistent with Tierney et al (2002), who assert that a high quality relationships between employees and supervisors lead to high levels of job satisfaction. In addition, Trompenaars (1984) indicated that in collectivist cultures, such as Mexico, employees tend to have a strong sense of loyalty to their supervisors and to the firm where they work. Consequently, having a close knit and collaborative relationship are very important. These findings validate the opinion that establishing relationships with employees is an essential pre-condition for leader effectiveness. It is particularly important due to Hispanic collectivist cultural background (Hofstede, 1984; Kraus, 1989), that supervisors should take additional time to develop a more personal relationship with their Hispanic subordinates. Furthermore, Tierney et al (2002) stressed the importance of interpersonal relationship on workperformance by finding that residual components of job satisfaction (e.g. pay, physical working conditions) are not sufficient to encourage altruist behavior with Mexican employees. These findings agree on the need to have a stronger understanding and appreciation of the cultural values that are inherent to the Hispanic workforce. De Forrest (1994) and Chen (2001) found that (1) supervisor-employee relationship, (2) group acceptance, and (3) organizational commitment have a strong impact on the level of job satisfaction for the Hispanic professionals. Moreover, in a study 
about diversity in the public sector, Rubaii-Barret and Beck (1993) found that Mexican Americans have a strong sense of community and maintain an effective, informal network of communication.

These findings are consistent in indicating that for the Hispanic culture, a personal relationship is of the utmost importance and that supervisors need to cultivate good relationships with their employees. Hispanics (Mexican Americans included) emphasize harmonious, cooperative, and non-conflictive work environment, where the emphasis is placed on cooperation among co-workers rather than competition. These studies agreed that a critical element is that promotion and status are important to Hispanic professionals; however it is critical for them to trust that supervisor's decisions are fair and unbiased. Rubaii-Barret and Beck (1993) made four observations from their study: (1) Group identity is very strong among Mexican American employees. Consequently, managers should consider that an action directed to one employee may be interpreted as directed to the whole group. (2) Supervisors need to be trained in team building and problem-solving to produce a working environment that leads to bonding and cooperation among employees. (3) The connection between work performed and compensation should be clearly defined and consistently applied. (4) Organizations should continuously assess and improve the quality of supervision through regular training and education.

\section{Compensation and Job Satisfaction}

Research has demonstrated that two important predictors to job satisfaction are compensation and career growth (Ting, 1997), which are associated with developing individual job attitudes. Career growth has been discussed above within the context of work environment. The literature is minimal concerning compensation issues related to Hispanics. Handel (2000) found that most employees were satisfied with their pay and its components (e.g. incentives, stock option, cash recognition, etc.). In addition, employees like the perceived direct relationship between work performance and pay. Handel (2000) found that stock options appear to have much less impact in employee retention that is conventionally believed. Moyes and Cortes (2006) found Mexican American accounting professionals have greater overall job satisfaction, even when they were unsatisfied with their level of compensation and benefits compared to their Anglo-Saxon counterparts.

\section{METHODOLOGY}

\section{Research Design}

This study examines which factors may explain the under-representation of Hispanic Americans in the accounting profession and is guided by two research questions:

1. Which factors influence the level of job satisfaction perceived by Hispanic American (Mexican Americans in particular) accounting professionals?

2. Which factors influence the retention of Hispanic American (Mexican Americans) accounting professionals to remain with their current accounting employers?

In figure 1 the relationship between the independent and dependent variables of the first and second regression models are shown. This figure explains the six factors that are instrumental in determining the perceived level of job satisfaction as represented in the first regression model. These six factors are as follows: (1) Employee acceptance, (2) Supervision, (3) Compensation, (4) Job enjoyment, (5) Employee treatment, and (6) Corporate environment. The second regression model with the dependent variable representing the intention to remain with the present employer has the same six independent variables plus the perceived level of job satisfaction as the seventh independent variable. Perceived level of job satisfaction is the intervening variable between the six factors and the intention to remain with current employer.

\section{Questionnaire}

Survey instrument was designed to measure the influence of 78 variables upon the level of job satisfaction perceived by Hispanic American Accounting professionals. The respondents hold bachelor degrees in accounting 
from a southwestern university and graduated between 1980 and 2001. This university has the highest percentage of Hispanic students of the United States that accounts for almost 90 percent of its student body.

Figure 1: Job Satisfaction and Retention Model

\begin{tabular}{|l|l|l|}
\hline Employee Acceptance & \multicolumn{2}{|c|}{ Level of Job Satisfaction } \\
Supervision \\
Compensation \\
Job Enjoyment \\
Employee Treatment \\
Corporate Environment
\end{tabular}

The questionnaires contain 12 background questions, 12 work-environment questions, 9 mentoring questions, and 78 six-point Lickert scales questions measuring perceived level of job satisfaction, the intent to remain with current accounting employer, and an open-ended question requesting written comments from the respondents. In conducting the pilot test, the initial version of the questionnaire was critiqued by 35 accounting professors and certified public accountants. Their constructive comments resulted in numerous revisions to the original questionnaire.

We sent 1,000 questionnaires to the accounting graduates in each of the two mass mailings. From all the surveys collected, we have a total of 143 usable questionnaires (14.3 per cent response rate). A test of non-response bias was conducted between the first and second mass mailing groups to determine if the respondents were representative of the total population. The late respondents from the second mass mailing are used as proxies for the non-respondents (Oppenheim, 2001). Hotellings $\mathrm{T}^{2}$ is used to test the equality of the multivariate means of the first and second mailings. The results of this test indicate no significant difference across variables between early and late respondents.

\section{Descriptive Statistics}

Table 1 shows descriptive statistics about the 143 Hispanic American accounting professionals surveyed. From the 143 respondents, $80(56 \%)$ are females and $63(44 \%)$ are males. The age range of respondents is from 24 to 52 years. From those holding accounting certifications, 21 (16\%) are Certified Public Accountants, one person is a Certified Internal Accountant and 7 hold other professional accounting certifications.

In terms of their professional status, 18 (13\%) of the respondents work in public accounting firms, $36(25 \%)$ work in corporate accounting positions, 34 (24\%) work in accounting jobs with various government agencies, 9 (6\%) are self-employed as accounting practitioners, and $46(32 \%)$ work in non-accounting positions, of which many changed their careers from accounting to teaching in public schools.

The number of years that the respondents work in their current positions varies from less than five to 20 years as follows: $104(71 \%)$ reported they are in their current position between one and five years (which includes new graduates and those promoted to new positions), 24 (16\%) have between six to ten years in their positions, 13 (9\%) have between 11 to 15 years, and $6(4 \%)$ have the greater number of years of experience in their current position lasting between 16 and 20 years.

Most respondents are employed either by very small or very large firms. The size of the firms is determined by total number of employees, and the firm size was classified into four categories: 48 (33\%) respondents work for very small firms that have between 1 and 19 employees; 42 (28\%) work for small firms that have between 50 and 499 employees; 9 (6\%) work for large firms that have between 500 and 999 employees; and 48 (33\%) work for the very large firms that have over 1,000 employees. 
Table 1: Descriptive Statistics For Mexican American Accounting Professionals

\begin{tabular}{|c|c|c|}
\hline Gender & $\begin{array}{l}\text { Female Hispanic } \\
\text { Male Hispanic }\end{array}$ & $\begin{array}{l}80(55.9 \%) \\
63(44.1 \%) \\
\end{array}$ \\
\hline Age & $\begin{array}{l}\text { Minimum } \\
\text { Average } \\
\text { Maximum }\end{array}$ & $\begin{array}{l}24 \text { years } \\
36 \text { years } \\
52 \text { years }\end{array}$ \\
\hline Degrees & $\begin{array}{l}\text { Bachelor } \\
\text { MBA } \\
\text { MS-Accounting } \\
\text { JD }\end{array}$ & $\begin{array}{l}129 \\
14 \\
2 \\
3\end{array}$ \\
\hline Bachelor Graduation Year & $\begin{array}{l}\text { Earliest Year } \\
\text { Average } \\
\text { Most Recent Year }\end{array}$ & $\begin{array}{l}1980 \\
1993 \\
2001\end{array}$ \\
\hline Accounting Certification & $\begin{array}{l}\text { Certified Public Accountant } \\
\text { Certified Internal Accountant } \\
\text { Other }\end{array}$ & $\begin{array}{l}21 \\
1 \\
7\end{array}$ \\
\hline Highest Level of Parents' Education & $\begin{array}{l}\text { Elementary School Dropout } \\
\text { Junior High School Dropout } \\
\text { High School Diploma } \\
\text { College-No Degree } \\
\text { Associate Degree } \\
\text { Bachelor Degree } \\
\text { Master Degree } \\
\text { Doctoral Degree } \\
\text { Other Graduate Degree }\end{array}$ & $\begin{array}{l}50 \\
17 \\
29 \\
16 \\
4 \\
13 \\
8 \\
1 \\
9\end{array}$ \\
\hline Internships & Did internship while in College & 13 \\
\hline Profession & $\begin{array}{l}\text { Public Accounting } \\
\text { Corporate Accounting } \\
\text { Governmental Accounting } \\
\text { Self-Employed } \\
\text { Non-Accounting }\end{array}$ & $\begin{array}{l}18 \\
36 \\
34 \\
9 \\
46\end{array}$ \\
\hline $\begin{array}{l}\text { Total Number of Years in Current } \\
\text { Position }\end{array}$ & $\begin{array}{l}\text { Minimum } \\
\text { Average } \\
\text { Maximum }\end{array}$ & $\begin{array}{l}1 \text { year } \\
5 \text { years } \\
20 \text { years }\end{array}$ \\
\hline $\begin{array}{l}\text { Number of Job Changes Since } \\
\text { Bachelor Degree Graduation }\end{array}$ & $\begin{array}{l}\text { Minimum } \\
\text { Average } \\
\text { Maximum }\end{array}$ & $\begin{array}{l}0 \text { job } \\
2 \text { jobs } \\
10 \text { jobs }\end{array}$ \\
\hline $\begin{array}{l}\text { Total Number of Employees in Firm } \\
\text { (Firm Size) }\end{array}$ & $\begin{array}{l}\text { Minimum } \\
\text { Average } \\
\text { Maximum }\end{array}$ & $\begin{array}{l}<10 \text { employees } \\
100-500 \text { employees } \\
>1,000 \text { employees }\end{array}$ \\
\hline Mentoring System & $\begin{array}{l}\text { With Informal Mentoring System } \\
\text { With Formal Mentoring System }\end{array}$ & $\begin{array}{l}62 \text { firms } \\
40 \text { firms }\end{array}$ \\
\hline Mentor Being & $\begin{array}{l}\text { Same Sex } \\
\text { Opposite Sex }\end{array}$ & $\begin{array}{l}24 \text { mentors } \\
29 \text { mentors }\end{array}$ \\
\hline Mentor Being & $\begin{array}{l}\text { Same Race } \\
\text { Different Race }\end{array}$ & $\begin{array}{l}26 \text { mentors } \\
27 \text { mentors }\end{array}$ \\
\hline
\end{tabular}

Assuming the 143 respondents work for 143 different firms, 62 (43.4\%) firms operate informal mentoring systems, and 40 (28.0\%) firms had established formal mentoring systems. In those firms that have formal mentoring systems, management assigns one experienced manager as a mentor to each newly hired college graduate, who helps the new employee to assimilate into the corporate environment and also responds to all the mentoree's questions and concerns. In addition, 24 respondents were assigned mentors of the same sex, and 29 respondents were assigned mentors of the opposite sex. Also, 26 respondents were assigned mentors of the same race, and 27 respondents were 
assigned mentors of the opposite race. From this survey, we concluded that mentors are assigned to new employees in a random basis without regards to sex and race.

With respect to the respondents' parent education, 67 (47\%) parents dropped out of school, 45 (31\%) graduated from high school, and $31(22 \%)$ graduated from college. Close to half of the respondents with college degrees had parents who did not finish their schooling. It is particularly difficult for these 67 respondents to have a vision of what a college degree really means and to have long-term career planning, if their parents cannot understand the problems they face during college years and do not support them in their professional development.

\section{Data Analysis}

We reversed the values from 30 questions because they were written as negative statements on the questionnaire. Then, the data were analyzed using factor analysis (Principal Components with Varimax Rotation) and regression models. Factor Analysis reduced the 78 independent variables into 18 factor groups.

Each factor group contains independent variables that are highly correlated with each other, but no correlations exist among the factor groups. Table 2 shows which independent variables comprise each factor group. In analyzing the data, the first six of the 18 factor groups were selected to be the independent variables for the two upcoming regression models.

\section{First Regression Model: Level of Job Satisfaction}

In the regression model shown below, the dependent variable represents the level of job satisfaction perceived by 143 Hispanic accounting graduates, and the independent variables are the six factors shown in Table 3 .

$\begin{aligned} \text { JobSatLevel }= & \beta_{0}+\beta_{1} \text { Acceptance }+\beta_{2} \text { Supervision }+\beta_{3} \text { Compensation }++\beta_{4} \text { Enjoyment }+\beta_{5} \text { Treatment }+ \\ & \beta_{6} \text { Environment }+\in\end{aligned}$ where:

JobSatLevel $=\quad$ Level of job satisfaction perceived by Hispanic American accounting Professionals

Acceptance $=$ Employee acceptance by peers and supervisors

Supervision $=$ Supervisory issues of Hispanic American accounting professionals

Compensation $=$ Dollar amount of compensation paid to Hispanic American accounting Professionals

Enjoyment $=$ Hispanic American accounting professional enjoyment of their jobs

Treatment $=\quad$ Hispanic American accounting professional treatment regardless of their race and gender

Environment $=$ Job environment of Hispanic American accounting professionals

Table 3 shows the coefficients, $\mathrm{t}$ values, $\mathrm{F}$ value, $\mathrm{R}$ square values, and significance levels for the first regression model, where the dependent variable is the level of job satisfaction of the Hispanic American accounting professionals.

Employee Acceptance

In reference to the first regression model, employee acceptance by management and peers is positively and significantly $(\mathrm{p}=.018)$ related to the level of job satisfaction perceived by the Hispanic American accounting professionals. The study showed that the following employee acceptance variables are important in increasing their job satisfaction: (1) when they are included in a variety of team projects, (2) they have helpful feedback from their supervisors, (3) they are involved in the decision making process, (4) they feel that they are treated as individuals rather than as members of a particular ethnic group, (5) they are assigned projects that increase their visibility, and (6) they are invited to non-work activities. These respondents feel that they are respected by their employers and they are allowed to increase their participation in performing their tasks and projects, which both help to advance their careers and ultimately increase their job satisfaction. 
Table 2: Variables Grouped Into Factors

\begin{tabular}{|c|c|}
\hline Factor Names & Variable Names \\
\hline Employee Acceptance & $\begin{array}{ll}1 & \text { I am invited to attend all meetings to which employees at my level are invited. } \\
2 & \text { I am included in a variety of team projects. } \\
3 & \text { My supervisor gives me helpful feedback about my performance. } \\
4 & \text { My supervisor treats me as an individual not as a member of a particular racial group. } \\
5 & \text { My supervisor involves me in the decision making process when appropriate. } \\
6 & \text { I would not be helpful to report a discriminatory action against me to my supervisors. } \\
7 & \text { My company encourages openness regarding gender and racial diversity. } \\
8 & \text { My supervisor assigns me projects that increase my visibility in the organization. } \\
9 & \text { I know what it takes to succeed in my organization. } \\
10 & \text { My colleagues invite me to non-work activities. } \\
\end{array}$ \\
\hline Supervision & $\begin{array}{ll}1 & \text { My supervisor is quite competent in doing his/her job. } \\
2 & \text { My supervisor does not appear to consider gender in making job assignments. } \\
3 & \text { My opportunity for promotion is the same as others in spite of me gender. } \\
4 & \text { My opportunity for raises is the same as other employees in spite of my gender. } \\
5 & \text { My supervisor watches my work more closely than that of others with similar experience. }\end{array}$ \\
\hline Compensation & $\begin{array}{ll}1 & \text { I feel I am being a fair amount for the work I do. } \\
2 & \text { Raises are too few and far between. } \\
3 & \text { I feel satisfied with my changes for salary increases. } \\
4 & \text { I do not feel my efforts are rewarded the way they should. }\end{array}$ \\
\hline Job Enjoyment & $\begin{array}{ll}1 & \text { I like going the things I do at work. } \\
2 & \text { I feel a sense of pride in doing my job. } \\
3 & \text { My job is enjoyable. } \\
4 & \text { My current job meets my pre-employment expectations. } \\
5 & \text { My current job is not as rewarding as I expected it to be. } \\
6 & \text { For the most part, I look forward to going to work. } \\
\end{array}$ \\
\hline Employee Treatment & $\begin{array}{l}1 \text { My supervisor at work treats me differently than other employees due to my racial background } \\
2 \text { My peers at work treat me differently because of my racial performance. } \\
3 \text { My supervisor treats me differently due to my gender. }\end{array}$ \\
\hline Job Environment & $\begin{array}{ll}1 & \text { My supervisor shows too little interest in the feelings of subordinates. } \\
2 & \text { There is too much bickering and fighting at work. } \\
3 & \text { Work assignments are not fully explained. }\end{array}$ \\
\hline
\end{tabular}

Table 3: First Regression Model - Level Of Job Satisfaction

JobSatLevel $=\beta_{0}+\beta_{1}$ Acceptance $+\beta_{2}$ Supervision $+\beta_{3}$ Compensation $+\beta_{4}$ Enjoyment $+\beta_{5}$ Treatment $+\beta_{6}$ Environment $+\epsilon$

\begin{tabular}{|cccc|}
\hline Factor Name & Coefficient & t-value & p-value \\
Acceptance & .152 & 2.407 & .0180 \\
Supervision & -.116 & -1.768 & .0800 \\
Compensation & .161 & 2.881 & .0050 \\
Enjoyment & .616 & 9.665 & .0005 \\
Treatment & .028 & .478 & .6330 \\
Environment & .193 & 3.427 & .0010 \\
Constant & & -.288 & .7740 \\
& & & Significance \\
R-square & Adjusted R-square & F-value & .0005 \\
.776 & .760 & 47.700 & \\
\hline
\end{tabular}

\section{Supervision}

Supervisory issues have a negative and marginally $(\mathrm{p}=.08)$ significant relation with the level of job satisfaction perceived by the Hispanic American accounting professionals. These professionals react negatively when 
their supervisors watch more closely their performance than that of their peers with similar experience. This finding represents a borderline significant relationship between supervision and levels of job satisfaction.

\section{Compensation}

Employee compensation is positively and significantly $(\mathrm{p}=.005)$ related to the level of job satisfaction perceived by the Hispanic American accounting professionals. This significance indicates that these professionals perceived fairness concerning the compensation paid in relation to the amount of the work performed.

\section{Job Enjoyment}

The employee enjoyment of their jobs is positively and significantly $(p=.0005)$ related to the level of job satisfaction perceived by the respondents. These Hispanic professionals express their likeness and enjoyment in their jobs to the point of feeling a sense of pride and look forward to going to work. Their jobs satisfy their preemployment expectations and are perceived as rewarding as they expected.

\section{Equal Treatment to Employees Regardless of Race and Gender}

Employee treatment from supervisors and peers regardless of race and gender is not significantly $(p=.633)$ related to the level of job satisfaction perceived by the Hispanic American accounting professionals. Since these respondents are working in a predominantly Hispanic area, it is not surprising that this factor is not an issue for increasing their perceived satisfaction with their current employer.

\section{Corporate Environment}

The corporate environment is positively and significantly $(\mathrm{p}=.001)$ related to the level of job satisfaction perceived by the Hispanic American accounting professionals. Hispanic accounting professionals feel that their job satisfaction increases: (1) when their supervisor shows interest in their feelings, (2) when there is little bickering and fighting at work, and (3) when job assignments are fully explained. This friendly and supportive environment can only increase job satisfaction.

\section{Second Regression Model: Intention to Remain with Current Employer}

In the regression model shown below, the dependent variable represents the intention to remain with current employer, and the independent variables are the six factors shown in Table 3 plus the independent variable, perceived level of job satisfaction, which previously was the dependent variable for the first regression model.

IntentToRemain $=$ $\beta_{0+} \beta_{1}$ JobSatLevel $+\beta_{2}$ Acceptance $+\beta_{3}$ Supervison $+\beta_{4}$ Compensation $+\beta_{5}$ Enjoyment + $\beta_{6}$ Treatment $+\beta_{7}$ Environment $+\epsilon$

where:

IntentToRemain $=$ JobSatLevel $=$ Acceptance $=$ Supervision $=$ Compensation $=$ Enjoyment $=$ Treatment $=$ Environment $=$
Hispanic American accounting professional intention to leave current accounting employer Level of job satisfaction perceived by Hispanic American accounting Professionals Employee acceptance by peers and supervisors Supervisory issues of Hispanic American accounting professionals Dollar amount of compensation paid to Hispanic American accounting professionals Hispanic American accounting professional enjoyment of their jobs Hispanic American accounting professional treatment regardless of their race and gender Job environment of Hispanic American accounting professionals 
Table 4 shows the coefficients, $\mathrm{t}$ values, $\mathrm{F}$ value, $\mathrm{R}$ square values, and significance levels for the second regression model, in which the dependent variable is the Hispanic American accounting professional intention to remain with their current accounting employers.

Table 4: Second Regression Model - Intention To Remain With Current Employer

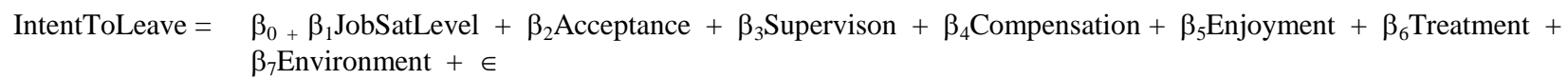

\begin{tabular}{|cccc|}
\hline Factor Name & Coefficient & t-value & P-value \\
JobSatLevel & .654 & 5.178 & .0005 \\
Acceptance & -.082 & -.888 & .3760 \\
Supervision & -.014 & -.144 & .8860 \\
Compensation & .127 & 1.573 & .1190 \\
Enjoyment & .086 & .723 & .4710 \\
Treatment & -.040 & -.479 & .6330 \\
Environment & -.019 & -.227 & .8210 \\
Constant & & .361 & .7190 \\
& & F-value & Significance \\
R-square & Adjusted R-square & 18.157 & .0005 \\
.532 & .502 & &
\end{tabular}

Level of Job Satisfaction Perceived by the Hispanic American Accounting Professionals

In reference to the second regression model, the Hispanic American perceived level of job satisfaction is positively and significantly related $(\mathrm{p}=.0005)$ with their intention to remain with current employers. It is natural that Hispanic American accounting professionals experiencing a very high level of job satisfaction indicate a very strong probability of remaining with their present employer through out their careers. In addition, perceived level of job satisfaction is the only predictor of the accounting professionals' intention to remain with existing employer as a result of the first regression model.

\section{Compensation}

The employee compensation amounts have a marginally and positively significant $(\mathrm{p}=.119)$ relationship with their intention to remain with their current employers. Compensation represents the universal, extrinsic motivator for employees to provide services to their employers. Consequently, we expect to have at least a certain level of positive relationship between compensation amount and the employees' intention to remain with their employers.

\section{Employee Acceptance, Supervision, Job Enjoyment, Employee Treatment and Corporate Environment}

The five remaining independent variables are not significantly related to their intention to remain with their current employers. These independent variables are: (1) the employee acceptance by management and peers $(\mathrm{p}=$ .376), (2) supervisory issues ( $\mathrm{p}=.886)$, (3) the employee enjoyment of their jobs $(\mathrm{p}=.471)$, (4) employee treatment from supervisors and peers regardless of race and gender $(\mathrm{p}=.663)$ and, $(5)$ the corporate environment $(\mathrm{p}=.821)$. These five independent variables are positively and significantly correlated with the level of job satisfaction, which in turn is positively and significantly correlated with the intent to remain with employer, thus, confirming the model that states that the level of job satisfaction is the intervening variable between the six identified factors and the intention to remain with present employer. The second regression model proved intention to remain with employer is highly dependent upon the perceived job satisfaction. 


\section{CONCLUSIONS}

This study is focused on the determinants of job satisfaction and retention of Hispanic Americans in the accounting professional. Our findings show that most of Mexican American accounting professionals was satisfied with their job and profession, which is supported by prior studies. We found that Mexican Americans have high levels of job satisfaction which may explain their desire to remain with present employer.

In the study, the level of job satisfaction of Hispanic American accounting professionals was influenced by the following six factors: employee acceptance, fair supervision, adequate compensation, job enjoyment, equal treatment to all employees regardless of race and gender, and corporate environment. Job satisfaction is the mediating factor that influences the decision to remain with present employer and the profession.

It is also important that this study confirm that the cultural factors of the Mexican American accounting professional are still present in their Hispanic heritage. Hofstede $(1980,2001)$ classified most Latin countries, including Mexico, as high in collectivism; compared with the United States, that is the lowest in collectivism (high individualism). This cultural characteristic is latent when the respondents perceive higher level of job satisfaction, while they feel more accepted from their supervisors and peers.

Hall $(1976,1990)$ identified Latin cultures as high context in communication, which emphasized personal relationships, trust and a more holistic approach to business decisions. Consistent with this cultural factor, the Mexican American respondents indicated that it was critical to trust that the supervisors' decisions were fair and unbiased. In addition, working in a supportive and friendly corporate environment was very important for them. Supportive environment is more salient that higher compensation. These findings are consistent with Hawkes et al. (1984), who found that the level of acceptance by peers in more important factor than the level of compensation in defining job satisfaction. No surprisingly, the intention of Hispanic American accounting professionals to remain with current accountancy employer depends primarily of their perceived level of job satisfaction.

Cultural differences need to be recognized by employers in order to successfully attract and retain Hispanic American accounting professionals to address the under-representation of this group in the profession. Knowledge resulting from this study may help Accounting firms to introduce cultural sensitivity programs that will enhance the understanding of cultural diversity, hence creating a more friendly and supportive environment, which in turn enhance creativity and loyalty to the firm.

\section{REFERENCES}

1. American Institute of Certified Public Accountants (AICPA), Minority Initiatives Committee, Academic and Career Development. 1998. Report on Minority Accounting Graduates, Enrollment and Public Accounting Professionals-1997. For Academic Year 1995-96. Jersey City, NJ: AICPA.

2. American Institute of Certified Public Accountants (AICPA), Academic and Career Development Team. 2003. The Study of Accounting Graduates and the Demand for Public Accounting Recruits-2003. For Academic Year 2001-2002. Jersey City, NJ: AICPA.

3. Bartell, A. P. 1981. Race differences in Job Satisfaction: A Reappraisal. Journal of Human Resources (February): 291-294.

4. Chen, X. 2001. Further Investigation of the Outcomes of Loyalty to Supervisor Job Satisfaction and Intention to Stay. Journal of Managerial Psychology 16 (July/August): 650-660.

5. Chusmir, L. H. and C. S. Koberg. 1990. Ethnic Differences in the Relationship Between Job Satisfaction and Sex-Role Conflict Among Hispanic and Non-Hispanic White Individuals. Psychological Reports, 568578.

6. Dallas Morning News. 2003. White House, Groups Promote Hispanic Education (July 10).

7. De Forrest, M. E. 1994. Thinking of a Plant in Mexico? Academy of Management Executive 8: 33-40.

8. De los Santos, G., E. C. Hume, and A. C. Cortes. 2002. Improving the Faculty's Effectiveness in Increasing the Success of Hispanic Students in Higher Education - Pronto! Journal of Hispanic Higher Education 1 (3): 225-237. 
9. Douvan, E. 1976. The Role of Models in Women's Professional Development. Psychology Of Women Quarterly 1: 5-15.

10. Green, K. C. 1992. After the Boom: Management Majors in the 1990s. New York, NY: McGraw-Hill.

11. Hall, E. T. 1976. Beyond Culture. New York, NY: Doubleday.

12. Hall, E. T. 1990. The Hidden Dimension. New York, NY: Anchor Books

13. Handel, J. 2000. Job Value: Employee are in the Driver's Seat. Workspan 46 (6): 28-32.

14. Hawkes, G. R., G. A. Guagnano, C. Acredolo, and S. A. Helmich. 1984. Status Inconsistency and Job Satisfaction: General Population and Mexican American Sub-Population Analysis. Sociology and Social Research March, 378-387.

15. Hofstede, G. 1980. Culture's Consequences International Differences in Work-Related Values. Newbury Park, CA: Sage.

16. Hofstede, G. 1984. The Cultural Relativity of the Quality of Life Concept. Academy of Management Review 9: 389-398.

17. Hofstede, G. 2001. Culture's Consequences. Comparing Values, Behaviors, Institutions, and Organizations Across Nations. Thousand Oaks, CA: Sage

18. Kraus, E. E. 1989. Management in Two Cultures: Bridging the Gap Between the U.S. and Mexican Managers. Yarmouth, ME: Intercultural Press.

19. Lankau, M. J. and T. A. Scandura. 1996. An Examination of Job Attitudes of White, Black and Hispanic Nurses in a Public Hospital. International Journal of Public Administration 19 (3): 77-398.

20. Leppel, K. 2001. Race, Hispanic Ethnicity, and the Future of the College Business Major in The United States. Journal of Education for Business (March/April).

21. McNeely, R. L. 1989. Job Satisfaction and Other Characteristics Among Hispanic-American Human Service Workers. Social Casework: The Journal of Contemporary Social Work (April): 237-342.

22. Moyes, G. D. and A.C. Cortes (2006) Differences in Work-Related Values Between the Mexican-Americans and Anglo-American Accounting Professionals. Journal of Business and Economic Research 4(7): 15-28.

23. Mynatt, P. G., Omundson, J.S., Shroeder, R. G., and Stevens, M. B. 1997. The Impact of Anglo And Hispanic Ethnicity, Gender, Position, Personality and Job Satisfaction on Turnover Intentions: A Path Analytic Investigation. Critical Perspective on Accounting (8): 657-683.

24. Oppenheim, A. N. 2001. Questionnaire Design, Interviewing and Attitude Measure. New Edition. New York, NY: Continuum.

25. Rubaii-Barret, N. and A. C. Beck. 1993. Minorities in the Majority: Implications for Managing Cultural Diversity. Public Personnel Management 22 (4): 503-521.

26. Ting, Yuan. 1997. Determinants of Job Satisfaction of Federal Government Employees. Public Personnel Management 25(3): 313-334.

27. Tierney, P., Bauer, T. N., and R. Potter. 2002. Extra-Role Behavior Among Mexican Employees: The Impact of LMX, Group Acceptance and Job Attitudes. International Journal of Selection and Assessment (December) 10 (4).

28. Trompenaars, F. 1984. Riding the Waves of Culture: Understanding Diversity in Global Business. New York, NY: Irwin Publishing.

29. U.S. Census Bureau. 1998. Table 1: Selected Social Characteristics of All Persons and Hispanic Persons by Type (February 3). Retrieved from www.census.gov/population/socdemo/hispanic/cps96/sumtab-1.txt.

30. U.S. Census Bureau, U.S. Department of Commerce, Economics and Statistics Administration: 2003. The Hispanic population in the United States: March 2002 (June).

31. Wheeler, C. D. 2004. Where Do You Want to Work? Diversity Equals Productivity. Hispanic Career World (July). 
NOTES 